\title{
Concept Analysis of Interpersonal Skills in Nursing
}

* This article derives from the dissertation entitled "Competencia interpersonal del docente de enfermería: génesis e influencias mutuas en la formación del estudiante de enfermería", Doctorate Program in Nursing, Nursing School, Universidad Nacional de Colombia. Available from: https://repositorio.unal.edu.co/handle/unal/78501

\section{凶Jennifer Rojas Reyes}

https://orcid.org/oooo-0001-8962-5135. Nursing School, Universidad de Antioquia, Colombia. jennifer.rojasr@udea.edu.co

\section{Luz Nelly Rivera Álvarez}

https://orcid.org/0000-0001-8750-1155. Nursing School, Universidad Nacional de Colombia, Colombia. Inriveraa@unal.edu.co

Received: 05/01/2021

Sent to reviewers: 25/05/2021 Approved by reviewers: 20/09/2021

\section{DOI: 10.5294/aqui.2022.22.1.3}

Para citar este artículo / To reference this article / Para citar este artigo

Rojas J, Rivera LN. Concept Analysis of Interpersonal Skills in Nursing. Aquichan. 2022;22(1):e2213. DOI: https://doi.org/10.5294/aqui.2022.22.1.3 
Topic: Epistemology.

Contribution to the discipline: Concept analyses are considered theoretical research because they contribute to advancing nursing knowledge. In this case, the concept of interpersonal skills in nursing makes the core relational aspects of nursing visible and defines the characteristics of a professional within practice. 


\section{Abstract}

Objective: To determine a broad definition of the term interpersonal skills in nursing. Materials and methods: This theoretical study follows Walker and Avant's method of concept analysis to examine the defining attributes of the concept. A literature search on interpersonal aspects of nursing was conducted in databases, e-books, and institutional repositories to recognize the uses, attributes, antecedents, consequences, and empirical referents of the concept. Experts on professional and relationship skills were consulted between 2009 and 2019. Results: This information was analyzed, concluding that interpersonal skills in nursing are defined as the abilities of professional nurses to express their knowledge, abilities, attitudes, and values in relationships with colleages, patients, and their relatives and achieve a humane and personcentered practice. Conclusion: The concept of interpersonal skills in nursing is limited, given a lack of clarity in practice and research on the indistinct use of terms related to interpersonal skills and interpersonal knowledge. This analysis advances nursing theory towards practice and research.

\section{Keywords (Source: MeSH)}

Nursing theory; professional competence; nursing; interpersonal skills; interpersonal relations; nursing research. 


\section{Análisis del concepto de competencia interpersonal en enfermería}

\section{Resumen}

Objetivo: determinar una definición amplia del término competencia interpersonal en enfermería. Materiales y métodos: en el presente estudio teórico, se aplica el método de análisis de conceptos de Walker y Avant para examinar los atributos definitorios del concepto. Se realizó una búsqueda bibliográfica sobre aspectos interpersonales de la enfermería en bases de datos, libros electrónicos y repositorios institucionales para reconocer los usos, los atributos, los antecedentes, las consecuencias y las referencias empíricas del concepto. Además, se consultó a expertos en habilidades profesionales y relacionales entre 2009 y 2019. Resultados: se analizó esta información y se concluyó que la competencia interpersonal en enfermería se define como la habilidad de los enfermeros profesionales para expresar sus conocimientos, destrezas, actitudes y valores en las relaciones con los colegas, los pacientes y sus familiares a fin de lograr una práctica humana y centrada en la persona. Conclusión: el concepto de competencia interpersonal en enfermería es limitado, dada la falta de claridad en la práctica y la investigación sobre el uso indistinto de términos relacionados con la competencia interpersonal y el conocimiento interpersonal. El presente análisis lleva la teoría de la enfermería hacia la práctica y la investigación.

Palabras clave (Fuente: MeSH)

Teoría de enfermería; competencia profesional; enfermería; habilidades interpersonales; relaciones interpersonales; investigación en enfermería. 


\section{Análise do conceito de competência interpessoal em enfermagem}

\section{Resumo}

Objetivo: determinar uma definição ampla da expressão "competência interpessoal em enfermagem". Materiais e métodos: neste estudo teórico, é aplicado o método de análise de conceitos de Walker e Avant para examinar os atributos que definem o conceito. Foi realizada busca bibliográfica sobre aspectos interpessoais da enfermagem em bases de dados, livros eletrônicos e repositórios institucionais para reconhecer os usos, os atributos, os antecedentes, as consequências e as referências empíricas do conceito. Além disso, especialistas em habilidades profissionais e relacionais foram consultados entre 2009 e 2019. Resultados: as informações foram analisadas e concluiu-se que a competência interpessoal em enfermagem é definida como a habilidade dos enfermeiros profissionais de expressar seus conhecimentos, destrezas, atitudes e valores nas relações com os colegas, com os pacientes e seus familiares a fim de atingir uma prática humana e focada na pessoa. Conclusões: 0 conceito de competência interpessoal em enfermagem é limitado, tendo em vista a falta de clareza na prática e na pesquisa sobre o uso indiscriminado de termos relacionados com competência interpessoal e conhecimento interpessoal. Esta análise leva a teoria da enfermagem à prática e à pesquisa.

Palavras-chave (Fonte: MeSH)

Teoria de enfermagem; competência profissional; enfermagem; relações interpessoais; pesquisa em enfermagem. 
Nursing competence comprise knowledge, abilities, attitudes, and behaviors integrated into and aimed at holistic care (1). This competence is not innate but developed in a complex process to which the environment and internal motivations contribute. Nursing competence is a multidimensional concept; its attributes include professional values, critical judgment, leadership, and effective interpersonal relationships $(1,2)$, the latter being the most relevant considering the growing need for human care in the world.

Developing behaviors aimed at establishing optimum interpersonal relationships do not always occupy essential places in institutional or educational nursing programs (3), in addition to the fact that nursing professionals with little experience find it difficult to put into practice effective methods to build up relationships with care recipients (3). Therefore, the need for interpersonally competent nurses is explicit.

Then, care as affection and interpersonal relationship (4) shows that these aspects are the most important for interpersonal skills in nursing. Care as affection reflects the emotional commitment to the other, and care as an interpersonal relationship is the essence of caring; it is the means through which the other is reached, which requires a genuine interest in the welfare of the other $(5,6)$. In other words, the interpersonal dimension of care establishes the ontological and epistemological aspects of the relationships with the subjects of care, the interpersonal nursing skills being necessary.

When inquiring about this topic within the literature and practice, concepts such as social skills, communicative aptitudes, communicative skills, relational knowledge, among others, are commonly used. However, the term "skill" is not fully grasped, and, as it is not clearly defined, a conceptual void is left. Therefore, a concept analysis of interpersonal skills in nursing is required.

For clarity purposes, concept analysis is a theoretical development strategy of the discipline, even being considered a form of theoretical research in nursing (7). It is a strategy that allows examining the attributes or characteristics of a term; it is a formal linguistic exercise that must be rigorous and precise to approach a definition, focusing on the potential and actual uses of words that convey the meanings of a concept (8). In this case, the term interpersonal skills in nursing arises from an attempt to narrow down the diversity of concepts on relational function in nursing found in the literature that are unclear to be used in research and applied in practice. This article aims to provide a broad definition of interpersonal skills in nursing as a theoretical approach that contributes to nursing research, practice, and education.

\section{Materials and methods}

A concept analysis was carried out as the most suitable and rigorous method to define the concept of interpersonal skills in nursing. 
Comparing the different forms of analysis, Walker and Avant's (8) methodology has fewer steps to follow than Wilson's (8), which allows to exemplify what the concept is and is not; in contrast to Rodger (9), which only includes the model case and it does not require explicit assumptions as proposed by Meleis (7). Walker and Avant's steps were followed for concept analysis: 1) Select a concept; 2) Determine the aim and purpose of the analysis; 3 ) Identify all uses of the concept; 4) Identify the defining attributes of the concept; 5) Construct a model case; 6 ) Construct borderline, related, and contrary cases; 7) Identify antecedents and consequences; 8) Define empirical referents.

Two strategies were employed to gather information on the concept and perform the analysis: literature search and consultation with an expert in the field. Both strategies are described below:

Literature search: It was conducted in Science Direct, Pubmed, Medline, Academic Search Complete, PsycARTICLES, BVS, and Scopus databases. We narrowed down the search to articles written in English, Spanish, and Portuguese and published between 2009 and 2019. This time range is adequate to cover the theoretical-conceptual evolution and the current state of the topic because the initial search yielded results per year, with a marked increase in articles related to professional competence and interpersonal skills in nursing since 2009. DeCS and MeSH terms 'nursing research,' 'nursing education research,' 'nursing practice,' 'professional competence,' and 'interpersonal skills' were searched using the Boolean operators AND and OR.

The literature review only included research articles, dissertations, thesis, and books addressing interpersonal aspects in nursing. Critical appraisal of manuscripts that presented research results was conducted using CASPe tools (10). The search and selection strategy of manuscripts is described in Figure 1.

Subject experts: Although the concept analysis methodology does not explicitly consider nurses' experiences regarding the conception and uses of the concept, we decided to include two nurses. They were part of the main study of the dissertation in which this analysis is immersed and were interested (voluntarily) in talking about the subject. Thus, from their experience, they fed what was found in the literature. Given the scope and uses of the concept, knowing the nurses' definition of interpersonal skills was considered relevant. With their prior consent, these nurses with graduate degrees in nursing and education were invited to participate in a semi-structured interview. They have researched into professional competence and communication skills; both have extensive practical experience, and nowadays, they work as lectures in nursing schools and departments in Spain and Colombia. They were asked about their knowledge, perception, and definition of competence and interpersonal skills; the main questions asked were the following: "When talking about the concept of interpersonal skills in nursing, what is the first thing that comes to 
your mind? How do you define it? What aspects make it up? Answers were audio-recorded, transcribed, and analyzed according to relevant themes and attributes using Atlas ti.

Data analysis: The analysis of the information collected aims to follow the steps proposed in the concept analysis methodology, the literature review, and the consultation of subject experts. However, the review process is described according to Whittemore and Knafl (12), and the interviews with the experts were subjected to thematic analysis (13), as presented in Table 1. They were then compared with each other to define the critical attributes of the concept, as shown in the results.

Figure 1. Literature search and selection diagram
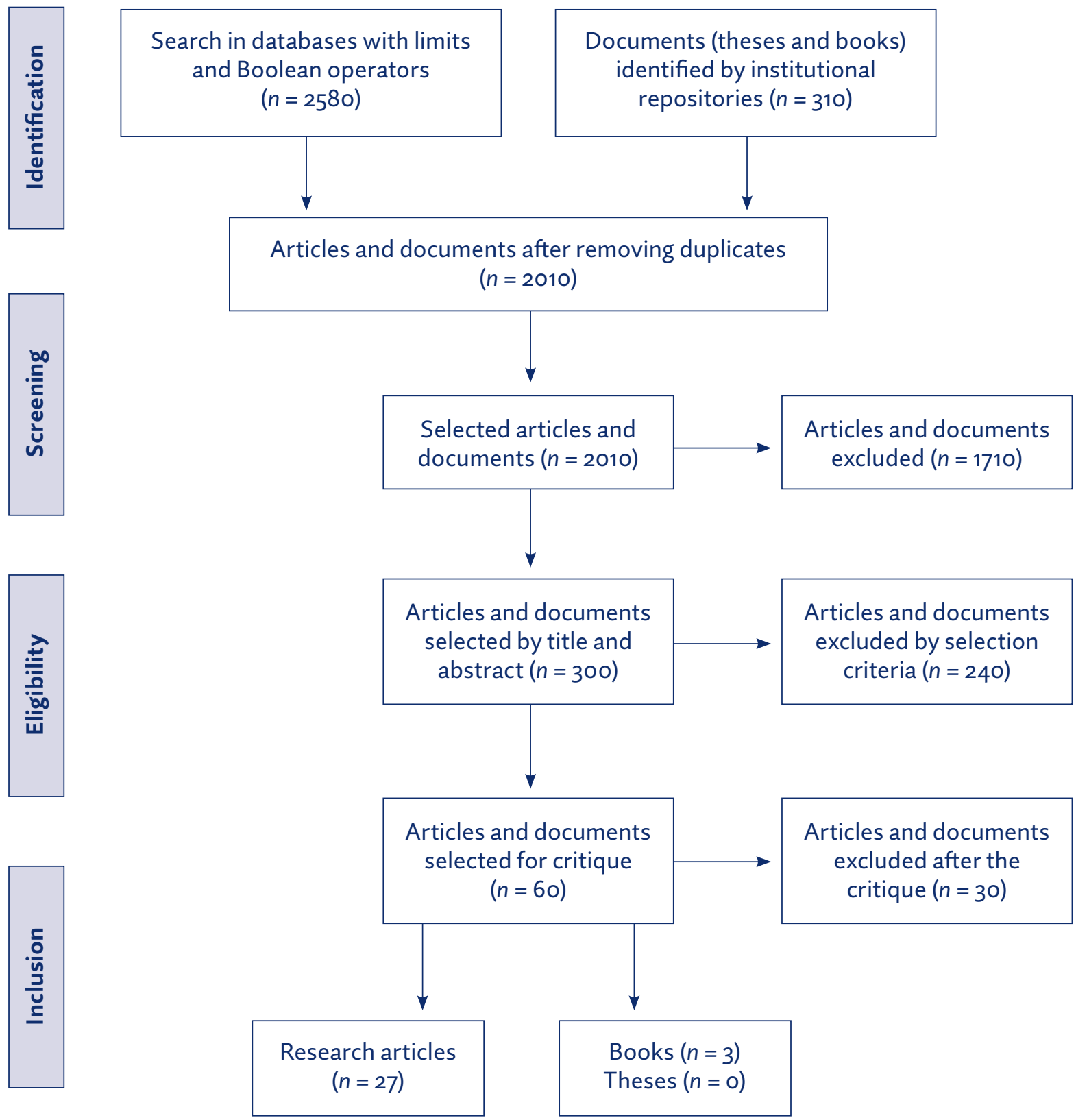

Source: Adapted from PRISMA Flow diagram for Scoping Review (11) 
Table 1. Analysis of the information collected

\begin{tabular}{|c|l|}
\hline \multicolumn{1}{|c|}{ Integrative review of the literature } & \multicolumn{1}{|c|}{ Thematic analysis of the interviews } \\
\hline $\begin{array}{l}\text { 1. Problem identification: The concept of interest arises } \\
\text { when conducting a limited search for the dissertation } \\
\text { in which the concept analysis is included. }\end{array}$ & $\begin{array}{l}\text { Phase 1. Getting familiar with the data/information: } \\
\text { The interviews are read during the transcriptions. }\end{array}$ \\
\hline $\begin{array}{l}\text { 2. Literature search: As presented in Figure 1 } \\
\text { 3. Data assessment: Critical reading is performed as } \\
\text { presented in Figure 1. }\end{array}$ & $\begin{array}{l}\text { Phase 3. Search for topics: The emerging codes related } \\
\text { detailed reading, the general topics are highlighted. } \\
\text { to the concept of interpersonal skills are gathered. }\end{array}$ \\
\hline $\begin{array}{l}\text { 4. Data analysis: The information is organized by } \\
\text { common characteristics, in this case, by the } \\
\text { attributes that represent the concept. }\end{array}$ & $\begin{array}{l}\text { Phase 4. Topic review: Codes are merged and } \\
\text { described from the data and part of the literature. }\end{array}$ \\
\hline $\begin{array}{l}\text { 5. Presentation of results: The antecedents, } \\
\text { consequences, and characteristics of the concept are } \\
\text { specified. }\end{array}$ & $\begin{array}{l}\text { Phase 5. Topic definition and naming: The topics } \\
\text { are named and defined according to the concept } \\
\text { concerned. }\end{array}$ \\
\hline $\begin{array}{l}\text { Phase 6. Production of the final report: The concept analysis is carried out, and the findings from the interviews } \\
\text { and the literature review are contrasted. }\end{array}$ \\
\hline
\end{tabular}

Source: Own elaboration

In analyzing the information from the literature and interviews, attributes and concepts emerged repetitively, showing strength in the data and characterizing the concept with aspects such as empathy, confidence, emotional intelligence, and negotiated decision making. These aspects are expanded in the uses of the concept and the critical attributes.

Finally, to follow the ethical principles of research, this concept analysis is embedded within a dissertation endorsed by the Ethics Committee of the Nursing School, Universidad Nacional de Colombia. Additionally, the participating experts signed informed consents for the interviews. This information is in possession of the first author, which will be retained and kept confidential for five years and then eliminated.

\section{Results}

Following the steps of concept analysis, the results are described below.

\section{Concept selection and aim of the analysis}

Multiple definitions of this term were found during the literature search on different nursing skills. However, when approaching the interpersonal aspects, we determined that the concept of interpersonal skills in nursing had not been clearly defined within the discipline since this concept tends to be confused with others, such 
as social skills, communication skills, empathy, or emotional intelligence, which, although linked, convey different meanings. Then, it is essential to clarify the meaning of interpersonal skills in nursing by offering a constitutive and operating definition.

\section{Uses of the concept}

The literature on the discipline and the experts in nursing skills were consulted to verify the uses of the concept. In this way, we could determine that the concept of interpersonal skills has been addressed mainly by nursing education research, clinical practice, and some nursing theories focused on interaction as a form of care. This section describes some aspects found in the literature review that can be divided into topics, as presented in Table 2 .

Table 2. Integrated evidence from the literature

\begin{tabular}{|c|c|}
\hline Topic & Characteristics \\
\hline $\begin{array}{l}\text { Beginnings and } \\
\text { origin of the } \\
\text { concept }\end{array}$ & $\begin{array}{l}\text { Conceptually, interpersonal skills in nursing began to be addressed by the Tuning Project (14). It } \\
\text { defined it as individual abilities to express one's feelings and to be critical and self-critical, social } \\
\text { skills related to interpersonal skills, ability to work in a team or to express social and ethical } \\
\text { commitment, and abilities that tend to facilitate social interaction processes in nursing (15). }\end{array}$ \\
\hline $\begin{array}{l}\text { Communication } \\
\text { skills in nursing }\end{array}$ & $\begin{array}{l}\text { The most outstanding nurses' skills, strategies, and gestures to communicate effectively include } \\
\text { empathy, negotiation skills; use of socio-culturally appropriate information; good intonation, } \\
\text { volume, and rhythm of the voice, body language, and facial expression. According to these } \\
\text { authors, all these aspects may be trainable }(16-18) \text {. } \\
\text { Regarding nursing education, some studies started from the positive teacher-student experience; } \\
\text { that is, when they understand each other, students' anxiety levels are reduced in practice settings } \\
(19,20) \text {. Then, the relationship modifies the student's behavior }(21) \text {. }\end{array}$ \\
\hline $\begin{array}{l}\text { Empathy and } \\
\text { emotional } \\
\text { intelligence }\end{array}$ & $\begin{array}{l}\text { Interpersonal skills in nursing comprises emotional skills (emotion expression and control, anxiety } \\
\text { management, among others) (22) and cognitive skills (interpreting the situation, perceiving others } \\
\text { correctly), which enable nurses to observe, interpret, and integrate a situation, and take an } \\
\text { empathic position (5). } \\
\text { Sociodemographic, labor, and academic variables seem to be related to emotional intelligence } \\
\text { and empathy (23). For senior nursing students, proper empathy, respect, and assertiveness levels } \\
\text { are associated with good performance during clinical practices }(24,25) \text {. Then, student's education } \\
\text { requires not only instrumental skills, but also affective skills }(26,27) \text {. }\end{array}$ \\
\hline $\begin{array}{l}\text { Negotiated } \\
\text { decision-making } \\
\text { in nursing care }\end{array}$ & $\begin{array}{l}\text { Some authors determined in their studies that situational aspects for both patient and nurse may } \\
\text { condition the quality of the established relationship, participation in care, and communication } \\
(28-30) \text {. } \\
\text { Research on end-of-life care found that nurses seek consensus and emotional support during } \\
\text { decision-making, which gives peace of mind to the person, the family, and the nurse (29). }\end{array}$ \\
\hline $\begin{array}{l}\text { Concept from } \\
\text { nursing theories }\end{array}$ & $\begin{array}{l}\text { Peplau affirms that nursing care is an interpersonal therapeutic process carried out through a } \\
\text { relationship between the individual and the nurse }(31,32) \text {. For Paterson and Zderad, nursing is } \\
\text { an intersubjective-transactional relationship between a nurse and a patient, where they share } \\
\text { experiences that lead to intersubjectivity, characterized by real presence and authentic sharing } \\
(33,34) \text {. Then, humane practice becomes the purpose of interpersonal skills in nursing. }\end{array}$ \\
\hline
\end{tabular}

Source: Own elaboration 
Finally, the literature review shows no clearly defined concept of interpersonal skills in nursing to work with for research and practice. What is clear is that interpersonal skills delimit knowledge, abilities, attitudes, and values applied to interpersonal relationships that nurses establish with care recipients and integrated into practical situations of care to ensure human care provision.

\section{Concept attributes}

The concept attributes allow us to approach a definition and recognize its characteristics. Interpersonal skills in nursing are made up of the knowledge, abilities, attitudes, and values expressed by nurses in recognition of the other person, in an authentic encounter that provides the interaction with therapeutic properties and positive effects for mutual growth (35) and favors the development of negotiation capacity and shared decision-making (36).

The development of interpersonal skills in nursing is mediated by attributes of interpersonal relationship such as trust, empathy, emotional intelligence, assertive communication, respect, openness towards others experiences, flexibility, social maturity, being in touch with one's and others' feelings, understanding, and negotiated decision-making (37). Interpersonal skills are also influenced by the nurse's experience and other interpersonal relationships, such as those involved in teamwork and work settings $(36,38)$.

Findings from the literature are supported by the experts' opinions about the subject. They consider interpersonal skills related to the formation of the self in nursing, the ability to reflect on interactions, nurses' previous and personal experiences, and communication as the cross-cutting factors of interpersonal relationships. Voices of the experts and topics discussed are shown in Table 3.

Table 3. Topics and voices of the experts interviewed

\begin{tabular}{|l|l|}
\hline \multicolumn{1}{|c|}{ Topics } & \multicolumn{1}{c|}{ Voices of the experts } \\
\hline $\begin{array}{l}\text { Formation of the self in nursing: That "self" } \\
\text { includes professional and personal values, } \\
\text { ethical principles, emotion management, } \\
\begin{array}{l}\text { and comprehension of the other person's } \\
\text { experience and meaning of health. }\end{array}\end{array}$ & $\begin{array}{l}\text { "If I don't work on all these aspects of the self, not just what has } \\
\text { to do with values, but also, for example, what has to do with } \\
\text { self-assurance, how will I tune up confidence and sureness in } \\
\text { a student who is going to lead health care teams and decision- } \\
\text { making processes in nursing care?" (Expert 02) }\end{array}$ \\
\hline $\begin{array}{l}\text { Communication as a basis for interpersonal } \\
\text { relationships: Conveying an idea in which } \\
\text { verbal and non-verbal expressions bear } \\
\text { meanings for both parties to understand and } \\
\text { help each other grow. }\end{array}$ & $\begin{array}{l}\text { "Interpersonal skills comprise] verbal language, non-verbal } \\
\text { language, contact, empathy, and communication. I think that } \\
\text { dialogue and communication are essential. These skills are just } \\
\text { as crucial between teacher and student as among nurses and } \\
\text { between doctor and nurse." (Expert 01) }\end{array}$ \\
\hline
\end{tabular}

Source: Data obtained from the analysis carried out by the authors in Atlas ti

For clarity purposes, critical attributes of the concept are presented in Table 4. These attributes represent what we found in the literature review, complemented and validated by the interviews carried out. 
Table 4. Critical attributes and surrogate terms of the concept

\begin{tabular}{|l|l|}
\hline \multicolumn{1}{|c|}{ Critical attributes } & \multicolumn{1}{c|}{ Definition } \\
\hline $\begin{array}{l}\text { Expression of the self of nursing } \\
\text { and its bioethical values, in which } \\
\text { the relationship has a therapeutic } \\
\text { or pedagogical aim (according to } \\
\text { the role of nursing) that produces } \\
\text { positive results. }\end{array}$ & $\begin{array}{l}\text { The self of nursing is abstract; however, it essentially provides care } \\
\text { as an interpersonal relationship (4), in which the connection and } \\
\text { interest in others' needs and vulnerable situations make nurses use } \\
\text { their sensitivity, trust, active listening, and respect as a means of } \\
\text { understanding and benefiting other people. }\end{array}$ \\
\hline $\begin{array}{l}\text { Ability to negotiate and make } \\
\text { decisions together with the other } \\
\text { person. Communicating needs }\end{array}$ & $\begin{array}{l}\text { Negotiated and jointly made care decisions foster horizontal } \\
\text { relationships and give value and importance to what other people think } \\
\text { about a situation. Other people may be students, patients, families, } \\
\text { communities, and work teams. }\end{array}$ \\
\hline $\begin{array}{l}\text { Identification and self-control of } \\
\text { emotions derived from shared } \\
\text { experiences }\end{array}$ & $\begin{array}{l}\text { Nurses should reflect on their own emotions, which are often difficult } \\
\text { to identify and control due to nurses' multiple adverse situations. So, } \\
\text { emotional intelligence is part of interpersonal skills in nursing. }\end{array}$ \\
\hline $\begin{array}{l}\text { Understanding the context where } \\
\text { other interpersonal relationships } \\
\text { established by nurses take place }\end{array}$ & $\begin{array}{l}\text { It means that part of the nurses' attitude may depend on other } \\
\text { relationships, such as those with colleagues and other professionals in } \\
\text { the health team. Literature shows that a good work environment fosters } \\
\text { good interpersonal relationships. }\end{array}$ \\
\hline
\end{tabular}

Source: Own elaboration

The self of nursing identifies with the essence of care that is the interpersonal relationship, which allows understanding the human health experience; in this dynamic, the need to identify and control emotions emerges, especially because experiences such as pain or death are difficult to handle when caring behaviors are marked by empathy and ethical principles of caring $(39,40)$. Consequently, the critical and reflective analysis of these situations helps the nurse understand the conceptions of health and care of people and the contexts in which care occurs, actively participating in decision-making. These characteristics enable us to recognize interpersonal skills in nursing.

In summary, interpersonal skills describe nurses' abilities to be open to others and their own experiences in the caring process. It involves knowing how to listen and communicate assertively, regulate emotions, be empathetic, respect and understand situations, help make negotiated decisions, and show a humane practice $(41,42)$. Besides, there are settings for teamwork that also affect the way interpersonal relationships are established.

\section{Case construction}

Subsequently, once exclusive characteristics of the concept are evident, the next step is taken, which is, at first sight, something simple but requires analytical thinking: case construction. The cases are constructed to illustrate what the concept is and is not, as follows:

\section{Model case}

An emergency nurse is caring for an older adult dying on a gurney in the hall, accompanied by his relative. The nurse decides to approach 
them because when she started her shift, she noted the patient's condition and the sad expression of his relative, so she greets them amicably and warmly, introduces herself, and asks them what they need. The patient's relative breaks into tears, and the nurse comforts him with a purposeful touch. The patient's relative tells her that he does not understand what is going on with his father and does not know if he is suffering exposed to the sight of everyone. The nurse listens to the patient's relative, answers his questions, and helps him say goodbye to his father. Then, understanding the situation and noting that there are no beds available in the inpatient unit, the nurse moves the patient to a more private area with an exclusive space for him and the relatives who wish to be there with him. The nurse informs the psychologist about the situation, and they together support the process of death and mourning, giving peacefulness to the family and dignity to the father's death.

\section{Borderline case}

An emergency nurse is caring for an older adult going through the dying process in the hall, accompanied by his relative. The nurse decides to approach them as she does with all her patients on each shift, greeting them and asking them what they need. The patients' relative breaks into tears, and she keeps silent and leaves for a moment. Then, she returns and informs the patient's relative that as there are no beds available in the inpatient unit, she will locate the patient in a more private place so that his family can say goodbye to him. Then, understanding the situation, the nurse informs the psychologist about the situation and, they together support the process of death and mourning.

\section{Related case}

An emergency nurse is caring for an older adult going through the dying process in the hall, accompanied by his relative. The nurse decides to approach them because she feels empathy, as she had liveda similar situation with her grandfather. She greets and asks them what they need, the patient's relative breaks into tears, and the nurse begins to talk to them about how important it is to say goodbye and be grateful for everything they shared and lived together. The nurse then informs the patient's relative that there are no beds available in the inpatient unit, but she will locate the patient in a more private place. There, the patient's relative expresses his feelings; the nurse listens to him and asks for support from the psychologist to support the process of death and mourning.

\section{Contrary case}

An emergency nurse is caring for an older adult going through the dying process in the hall, accompanied by his relative. The nurse approaches to give the patient the medications and notes that the patient's relative is sad; so, she decides to avoid the situation and only informs them that she is giving medications that relieve pain. 
The patient's relative asks her to please relocate them. She moves the patient to a more private area and tells them again that there are no beds available. She informs the treating physician and says that it is his job to support them in this process of death and mourning.

Comparing the model case versus the contrary case, Table 5 presents a specific analysis that makes explicit the differences between them.

Table 5. Comparison between cases

\begin{tabular}{|l|l|l|}
\hline \multicolumn{1}{|c|}{ Critical attributes } & \multicolumn{1}{|c|}{ Model case } \\
\hline $\begin{array}{l}\text { Expression of the self of nursing and } \\
\text { bioethical values }\end{array}$ & $\begin{array}{l}\text { The ethical principle of beneficence, } \\
\text { approaching others, and authentic } \\
\text { presence }\end{array}$ & $\begin{array}{l}\text { Minimum interest and } \\
\text { responsibility for the person's } \\
\text { situation }\end{array}$ \\
\hline $\begin{array}{l}\text { Ability to negotiate and make } \\
\text { decisions together/ communication }\end{array}$ & $\begin{array}{l}\text { Control of situations and decision- } \\
\text { making considering the family }\end{array}$ & $\begin{array}{l}\text { Superficial management of the } \\
\text { problem, unable to mediate care } \\
\text { decisions. }\end{array}$ \\
\hline $\begin{array}{l}\text { Identification and self-control of } \\
\text { emotions }\end{array}$ & $\begin{array}{l}\text { She manages to empathize with the } \\
\text { situation without being affected } \\
\text { emotionally }\end{array}$ & $\begin{array}{l}\text { Little control of emotions during } \\
\text { attention, runs away from the } \\
\text { situation. }\end{array}$ \\
\hline $\begin{array}{l}\text { Understanding the context of } \\
\text { others interpersonal relationships }\end{array}$ & $\begin{array}{l}\text { Good communication and } \\
\text { relationship with the team and } \\
\text { focuses attention on the patient }\end{array}$ & $\begin{array}{l}\text { There is no relationship with the } \\
\text { patient care team }\end{array}$ \\
\hline
\end{tabular}

Source: Own elaboration

\section{Identification of antecedents and consequences}

Antecedents are those aspects present before competence achievement, and consequences are those aspects that result from such competence.

As antecedents, nurses ought to have theoretical knowledge of interpersonal relationships, which is acquired during their professional training and from previous experiences such as the school and family education they received, especially values, morals, and ethics. Additionally, self-criticism and reflection on practical action should be strengthened to think and rethink the experiences derived from established relationships $(43,44)$.

Regarding the consequences of developing interpersonal skills, nurses will follow a humane practice, be genuinely present in the care they provide, be guided by bioethical principles, and efficiently work in teams $(45,46)$.

\section{Empirical referents: Methods and measurement instruments}

Few validated instruments are available to measure interpersonal skills in English and Spanish versions. Some scales that may mea- 
sure specific attributes or address interpersonal aspects are shown in Table 6. Research perspectives to approach this phenomenon show that experiences and the process of developing interpersonal skills in nursing have been researched from the qualitative point of view. Quantitatively, researchers have come close to describing the characteristics and relating each attribute to this concept.

Table 6. Measurement instruments related to the concept

\begin{tabular}{|c|l|l|}
\hline Concept & \multicolumn{1}{|c|}{ Instrument } & \multicolumn{1}{c|}{ Validity and Reliability } \\
\hline Caring Behavior & $\begin{array}{l}\text { Caring Behaviors Assessment (CBA) (47). } \\
\text { It is based on Watson's Theory. }\end{array}$ & $\begin{array}{l}\text { Cronbach's alpha: 0.96 } \\
\text { Content Validity (CVI): 0.93 (high) } \\
\text { Factor analysis with Varimax rotation of } \\
72 \% \text { explained variance }\end{array}$ \\
\hline $\begin{array}{c}\text { Caring Interpersonal } \\
\text { Relationships }\end{array}$ & $\begin{array}{l}\text { Assessment of nurse-patient interpersonal } \\
\text { relationship VRIEP-ICU (48). It is based } \\
\text { on the HANC model (humanism, patient } \\
\text { assistance, met need, and quality of care). }\end{array}$ & $\begin{array}{l}\text { Content Validity with Kappa index of } \\
\text { agreement of o.86 (high) } \\
\text { It needs tests for construct validity and } \\
\text { reliability. }\end{array}$ \\
\hline $\begin{array}{c}\text { Caring Interpersonal } \\
\text { Relationships }\end{array}$ & $\begin{array}{l}\text { Nursing Care Interpersonal Relationship } \\
\text { Questionnaire (49). It is based on Imogene } \\
\text { King's Conceptual Model. }\end{array}$ & $\begin{array}{l}\text { Cronbach's alpha: 0.90 } \\
\text { Content Validity: } \geq 0.78 \text { (high) } \\
\text { One factor explains 31.5\% variance. }\end{array}$ \\
\hline $\begin{array}{c}\text { Attributes of Care } \\
\text { Subjectivity }\end{array}$ & $\begin{array}{l}\text { Caring Assessment Scale Tool (CAT-V). It } \\
\text { is based on the Theory of Transpersonal } \\
\text { Human Caring. }\end{array}$ & $\begin{array}{l}\text { Cronbach's alpha: 0.95 } \\
\text { Three factors explain } 59.3 \% \text { variance. }\end{array}$ \\
\hline
\end{tabular}

Source: Own elaboration

\section{Implications for research, practice, and education}

Having conceptual clarity of the term interpersonal skills in nursing guides both the being and the duties of nursing professionals. Evidence shows a growing need to include it within the training practices of students (51) since interpersonal skills has become essential to provide care recipients with authentic and humane care. Despite being often intangible, interpersonal skills are perceptible to those who are receiving care.

However, approaching more factual knowledge, it is expected that the attributes derived from this analysis will guide future translational research through interventions that favor the development of these skills in nursing professionals and psychometric research to create specific scales for its measurement. The real impact will be on the patient cared for and their families by having nurses that make them visible and participants in their care.

\section{Conclusions}

After the literature review and the consultations with subject experts, we can affirm that interpersonal skills in nursing are the knowledge, abilities, attitudes, and values that nurses can express comprehensively during the interpersonal relationships they es- 
tablish with others, whether care recipients, family members, communities, colleagues, or other professionals. These skills are characterized by respect, openness to others' experiences, emotion management, commitment to others, empathy, negotiated and shared decision making, teamwork, and application of bioethical principles. Their purpose is to develop a humane nursing practice in which positive results are obtained therapeutically or pedagogically depending on the role played by the nursing profession.

Hopefully, this concept analysis will guide future research on measurement and assessment of interpersonal skills and the effect of educational programs that include interpersonal skills. Despite the different global settings in which nurses work today, interpersonal skills concern each country and each role nurses play.

Conflict of interest: The authors declare no conflict of interest in performing this concept analysis.

\section{References}

1. Smith SA. Nurse competence: A concept analysis. Int J Nurs Knowl. 2012;23(3):172-82. DOI: https://doi.org/10.1111/j.20473095.2012.01225.X

2. Garside JR, Nhemachena JZ. A concept analysis of competence and its transition in nursing. Nurse Educ Today. 2013;33(5):541-5. DOI: https://doi.org/10.1016/j.nedt.2011.12.007

3. Kim J. Factors influencing nursing students' empathy. Korean J Med Educ. 2018;30(3):229-236. DOI: https://doi.org/10.3946/ kjme.2018.97

4. Morse J, Solberg S, Neander W, Bottoroff J, Johnson J. Concepts of caring and caring as concept. Adv Nurs Sci. 1990;13(1):1-14. DOI: https://doi.org/10.1097/00012272-199009000-00002

5. Handan E, Ayse Sonay T. The relation between nursing students' levels of self-efficacy and caring nurse-patient interaction: $A$ descriptive study. Contemp Nurse. 2020;56(2):185-198. DOI: https://doi.org/10.1080/10376178.2020.1782763

6. Wu Y. Empathy in nurse-patient interaction: a conversation analysis. BMC Nurs. 2021;20(1):18. DOI: https://doi.org/10.1186/ s12912-021-00535-0

7. Meleis A. Theoretical nursing: Development \& progress. 5th ed. Pennsylvania, EEUU: Wolters Kluwer Health; 2012. 689 p.

8. Walker LO, Avant KC. Strategies for Theory Construction in Nursing. 6th ed. Boston, EEUU: Pearson Education; 2019. 251 p.

9. Rodgers BL, Knalf K. Concept Development in Nursing: Foundations, Techniques, and Applications. Philadelphia: Saunders; 2000.

10. CASPe (Critical Appraisal Skills Programme Español). Instrumentos para lectura crítica - Herramientas para análisis de reportes de investigación. [Internet]. Alicante, España; 2016. p. 3-8. Available from: http://www.redcaspe.org/herramientas/ instrumentos

11. Tricco AC, Lillie E, Zarin W, et al. PRISMA Extension for Scoping Reviews (PRISMA-SCR): Checklist and explanation. Ann Intern Med. 2018;169(7):467-73. DOI: https://doi.org/10.7326/M18-0850

12. Whittemore R, Knafl, K. The integrative review: updated methodology. J Adv Nurs. 2005;52(5):546-53. DOI: https://doi. org/10.1111/j.1365-2648.2005.03621.x
13. Braun V, Clarke V. Using thematic analysis in psychology. Qual Res Psychol. 2006;3(2):77-101. DOI: https://doi. org/10.1191/1478088706qpo63oa

14. Beneitone P, Esquetini C, Gonzalez J, Maleta M, Siufi G, Wagenaar R. Reflexiones y perspectivas de la educación superior en América Latina [Internet]. Informe Final-Proyecto TuningAmérica Latina 2011-2013. España; 2014. 1-432 p. Available from: http://www.tuningal.org/

15. Delaney KR, Shattell M, Johnson ME. Capturing the Interpersonal Process of Psychiatric Nurses: A Model for Engagement. Arch Psychiatr Nurs. 2017;31(6):634-40. DOI: https://doi.org/10.1016/j. apnu.2017.08.003

16. Tran TV, Tran TD, Nguyen AQ, Dinh TT, Le ATK, Tran HB. Nursepatient communication: A quality assessment in public hospital. Int J Healthc Manag. 2020;1-7. DOI: https://doi.org/10.1080/2047 9700.2020 .1752987

17. Bullington J, Söderlund M, Bos Sparén E, Kneck $\AA$, Omérov $P$, Cronqvist $A$. Communication skills in nursing: A phenomenologically-based communication training approach. Nurse Educ Pract. 2019;39:136-41. DOI: https:// doi.org/10.1016/j.nepr.2019.08.011

18. Fite RO, Assefa M, Demissie A, Belachew T. Predictors of therapeutic communication between nurses and hospitalized patients. Heliyon. 2019;5(10):e02665. DOI: https://doi.org/10.1016/j. heliyon.2019.e02665

19. Shorey S, Siew AL, Ang E. Experiences of nursing undergraduates on a redesigned blended communication module: $A$ descriptive qualitative study. Nurse Educ Today. 2018;61:7782. DOI: https://doi.org/10.1016/j.nedt.2017.11.012

20. Dalcól C, Garanhani ML, Fonseca LF, Carvalho BG. Competência em comunicação e estratégias de ensino-aprendizagem: percepção dos estudantes de enfermagem. Cogitare Enferm. 2018;23(3). DOI: https://doi.org/10.5380/ce.v23i3.53743

21. Sweet L, Broadbent J. Nursing students' perceptions of the qualities of a clinical facilitator that enhance learning. Nurse Educ Pract. 2017;22:30-36. DOI: https://doi.org/10.1016/j. nepr.2016.11.007 
22. Pérez-Fuentes MDC, Molero Jurado MDM, Gázquez Linares JJ, Oropesa Ruiz NF. The role of emotional intelligence in engagement in nurses. Int J Environ Res Public Health. 2018;15(9):1915. DOI: https://doi.org/10.3390/ijerph15091915

23. Giménez Espert C, Valero Moreno S, Prado Gascó VJ. Evaluation of emotional skills in nursing using regression and QCA models: A transversal study. Nurse Educ Today. 2019;74:31-7. DOI: https:// doi.org/10.1016/j.nedt.2018.11.019

24. Sánchez Expósito J, Leal Costa C, Díaz Agea JL, Carrillo Izquierdo MD, Jiménez Rodríguez D. Socio-emotional competencies as predictors of performance of nursing students in simulated clinical practice. Nurse Educ Pract. 2018;32:122-8. DOI: https://doi. org/10.1016/j.nepr.2018.07.009

25. Labrague LJ, McEnroe-Petitte DM, Tsaras K. Predictors and outcomes of nurse professional autonomy: A cross-sectional study. Int J Nurs Pract. 2018;25(1):e12711. DOI: https://doi.org/10.1111/ijn.12711

26. Soriano G, Aquino MG. Characteristics of a Good Clinical Teacher as Perceived by Nursing Students and Faculty Members in a Philippine University College of Nursing. Int J Nurs Sci. 2017;7(4): 96-101. Available from: http://article.sapub.org/10.5923.j.nursing.20170704.04.html

27. Parvan K, Hosseini FA, Bagherian S. The relationship between nursing instructors' clinical teaching behaviors and nursing students' learning in Tabriz University of Medical Sciences in 2016. Educ Health. 2018;31(1):32-38. DOI: https://doi.org/10.4103/13576283.239044

28. Riviere M, Dufoort $H$, Hecke A Van, Vandecasteele $T$, Beeckman $D$. Core elements of the interpersonal care relationship between nurses and older patients without cognitive impairment during their stay at the hospital: A mixed-methods systematic review. Int J Nurs Stud. 2019;92:154-72. DOI: https://doi.org/10.1016/j. ijnurstu.2019.02.004

29. Coad J, Smith J, Pontin D, Gibson F. Consult, Negotiate, and Involve: Evaluation of an Advanced Communication Skills Program for Health Care Professionals. J Pediatr Oncol Nurs. 2018;35(4):296-307. DOI: https://doi.org/10.1177/1043454218765136

30. Ludin SM. Does good critical thinking equal effective decision-making among critical care nurses? A cross-sectional survey. Intensive Crit Care Nurs. 2018;44:1-10. DOI: https://doi. org/10.1016/j.iccn.2017.06.002

31. Suhariyanto, Hariyati RTS, Ungsianik T. Improving the interpersonal competences of head nurses through Peplau's theoretical active learning approach. Enferm Clin. 2018;28:149-153. DOI: https://doi.org/10.1016/S1130-8621(18)30056-1

32. Hochberger JM, Lingham B. Archives of Psychiatric Nursing Utilizing Peplau's Interpersonal Approach to Facilitate Medication Self-Management for Psychiatric Patients. Arch Psychiatr Nurs. 2017;31(1):122-4. DOI: https://doi.org/10.1016/j.apnu.2016.08.006

33. Rubia Coelho N, Vergara LM. Teoría de Paterson E Zderad: aplicabilidade humanística no parto. Cogitare Enferm. 2015;20(4):82936. DOI: https://doi.org/10.5380/ce.v20i4.40323

34. Wu HL, Volker DL. Humanistic nursing theory: application to hospice and palliative care. J Adv Nurs. 2012;68(2):471-479. DOI: https://doi.org/10.1111/j.1365-2648.2011.05770.x

35. Stein Parbury J. Patient \& Person. Interpersonal skills in nursing. 7th ed. Sidney, Australia: Elsevier; 2020.

36. Grant A, Goodman B. Communication \& Interpersonal skills in nursing. 4th ed. California, EEUU: SAGE publications; 2019.
37. Reid Searl K, McAllister M, Dwyer T, Krebs KL, Anderson C, Quinney L, et al. Little people, big lessons: An innovative strategy to develop interpersonal skills in undergraduate nursing students. Nurse Educ Today. 2014;34(9):1201-6. DOI: https://doi. org/10.1016/j.nedt.2014.04.004

38. Pérez-Fuentes MdC, Molero Jurado MdM, del Pino RM and Gázquez Linares JJ. Emotional intelligence, self-efficacy and empathy as predictors of overall self-esteem in nursing by years of experience. Front Psychol. 2019;10:2035. DOI: https://doi. org/10.3389/fpsyg.2019.02035

39. Barlow NA, Hargreaves J, Gillibrand WP. Nurses' contributions to the resolution of ethical dilemmas in practice. Nurs Ethics. 2018;25(2):230-242. DOI: https://doi. org/10.1177/0969733017703700

40. Ming Y, Wei H, Cheng H, Ming J, Beck M. Analyzing Patients' Complaints. Awakening of the Ethic of Belonging. Adv Nurs Sci. 2019;42(4):278-288. DOI: https://doi.org/10.1097/ ANS.0000000000000278

41. Simões Ângela SP. Conceito de dignidade na enfermagem: análise teórica da ética do cuidado. Rev Bioet. 2019; 27(2):244-252. DOI: https://doi.org/10.159o/1983-80422019272306

42. McCaffrey G. A humanism for nursing? Nurs Inq. 2019;26(2):1-7. DOI: https://doi.org/10.1111/nin.12281

43. Sadlon PP. The process of reflection: A principle-based concept analysis. Nurs Forum. 2018;53(3):364-8. DOI: https://doi. org/10.1111/nuf.12251

44. Collier AD. Characteristics of an effective nursing clinical instructor: the state of the science. J Clin Nurs. 2018;27:363-74. DOI: https://doi.org/10.1111/jocn.13931

45. Bang M, Sim S. The relationship among personality, interpersonal relations and stress of clinical practice of nursing students. IJANER. 2016;1(1):69-74. DOI: https://doi.org/10.21742/IJANER.2016.1.1.12

46. Guevara Lozano M, Arroyo Marles LP, Pérez Giraldo B, Sánchez Herrera B. Commitment and Human Tone: The Difference between Traditional Service and Nursing Care. Invest Educ Enferm. 2019;37(1):40-49. DOI: https://doi.org/10.17533/udea.iee.v37n1eo5

47. Morales-Castillo FA, Hernández-Cruz MC, Morales Rodríguez MC, Landeros Olvera EA. Validación y estandarización del instrumento: Evaluación de los comportamientos de cuidado otorgado en enfermeras mexicanas. Enfermería Univ. 2016;13(1):3-11. DOI: https://doi.org/10.1016/j.reu.2015.11.005

48. Parrado Lozano YM, Sáenz Montoya X, Soto Lesmes VI, Guáqueta Parada SR, Amaya Rey P, Caro Castillo CV, et al. Validez de dos instrumentos para medir la relación interpersonal de la enfermera con el paciente y su familia en la unidad de cuidado intensivo. Investig Enfermería Imagen Desarro. 2016;18(1):115-28. DOI: https:// doi.org/10.11144/Javeriana.ie18-1.vimr

49. Borges JWP, Moreira TMM, de Andrade DF. Nursing Care Interpersonal Relationship Questionnaire: elaboration and validation. Rev Latino-Am Enfermagem. 2017;25:e2962. DOI: https://doi. org/10.1590/1518-8345.2128.2962

50. Fernández Ayuso RM, Morillo Velázquez JM, Fernández Ayuso, de la Torre-Montero JC. Validación al Español de la Herramienta de Evaluación de los Cuidados, Caring Assessment Tool (CAT-V). Rev Latino-Am Enfermagem. 2017;25:e2965. DOI: https://doi. org/10.1590/1518-8345.0920.2965 